\title{
Physicochemical Characteristics of Curdled Milk and Their Correlation with the Lactic Flora in Chad
}

\author{
Abdelsalam Adoum Doutoum \\ Graduate Institute of Science and Technology of Abeche (IUSTA) Abeche-Chad \\ Laboratory of Hygiene and Industry Foodstuffs of Animal Origin (HIDAOA) \\ EISMV, Dakar, Senegal
}

Abdelsalam Tidjani (Corresponding author)

Faculty of Human Health Sciences University of N'Djamena

P.O. Box 1117, N’Djamena, Chad

National Centre of Nutrition and Food Technology of the Public Health Ministry P.O. Box 440 N’Djamena, Chad

E-mail: abdelti@yahoo.fr / abdelti@gmail.com

Mamadou Baldé

Laboratory of Hygiene and Industry Foodstuffs of Animal Origin (HIDAOA)

EISMV, Dakar, Senegal

Safia Mahamat Tahir Tidjani

Graduate Institute of Science and Technology of Abeche (IUSTA) Abeche-Chad

Bellancille Musabyemariya

Laboratory of Hygiene and Industry Foodstuffs of Animal Origin (HIDAOA)

EISMV, Dakar, Senegal

Rianatou Alambedji

Laboratory of Microbiology

Immunology and Infectious Pathology (MIPI). EISMV, Dakar-Senegal 
Babakar Khalifa Serigne Sylla

Laboratory of Hygiene and Industry Foodstuffs of Animal Origin (HIDAOA)

EISMV, Dakar-Senegal

Malang Seydi

Laboratory of Hygiene and Industry Foodstuffs of Animal Origin (HIDAOA)

EISMV, Dakar-Senegal

Bhen Sikina Toguebaye

Department of Animal Biology, Faculty of Science and Technology - UCAD, Dakar-Senegal

Received: Oct. 6, 2013 Accepted: November 3, 2013 Published: December 1, 2013

doi:10.5296/jfs.v2i2.4388ＵRL: http://dx.doi.org/10.5296/jfs.v2i2.4388

\begin{abstract}
Milk and dairy products are highly consumed in Chad. Among dairy products, curd is very popular chadian consumers. In order to determine the values of various physicochemical parameters of curds, but also the relationships between these parameters and the lactic flora, a study was conducted during two years (2006 and 2008) in cold dry season and hot dry season. In total five locations was study during these two seasons. It was noted that there is a very significant difference between physicochemical parameters $(\mathrm{P}<0.005)$. Also, fermenting milk with micro-organisms leads to changes in the texture, color, taste, flavor and nutritional properties of milk. Similarly, bacterial species are different from one locality to another, although some species have been identified in the curdled milk of all areas of study. Fermenting milk leads to the formation of organic acids, especially lactic acid, resulting in acidification of the milk. Production of lactic acid during the fermentation results in a lowering of $\mathrm{pH}$ will cause the milk to curdle. It is therefore important to conduct this study in order to capitalize information on the characteristics of the curd according to the different seasons. This study would be a good tool for information and awareness on the quality of curd in Chad. It would be desirable that other much more sustained studies be carried out to identify the majority of lactic acid bacteria. This will allow better synergies in order to present for consumers the various curds of best organoleptic characteristic.
\end{abstract}

Key words: Milk curds, Physicochemical Parameters, Lactic flora 


\section{Introduction}

Milk is a nutritious food for humans. In Chad, milk and its products are consumed by many people including the curd its in various forms (Doutoum et al., 2013a; 2013b); it is favorable to the growth of many microorganisms particularly pathogenic bacteria (Chye et al., 2004). It should also be noted that the composition and physico-chemical characteristics of milk varies significantly between species and even between races (Soryal et al., 2004). These characteristics are also dependent on the nature of the feed (Sutton, 1989; Coulon et al., 1995.). Dairy products are considered nutrient-rich foods. They provide with grains, meats, vegetables and fruits, many nutrients in relatively low energy and essential to health throughout the life cycle (Drewnowski, 2005; Miller, Jarvis McBean, 2007). The processing of milk into dairy products with an economic life and greater conservation developed in dairy processing units. Koussou (2001) \& Duteurtre et al. (2005) indicates that in Chad, there is a renewed interest in local milk and traditional products such as fresh milk, fermented milk, clarified butter, which represented up to $65 \%$ of dairy products sold in major cities. In addition to their nutritional value, consumption of dairy products is associated with beneficial health effects (Takahiro et al., 2007). In Chad, the traditional milk curds are made in all suburban areas. These dairy products are very popular with consumers because of their ease of assimilation but also because of their organoleptic characteristics. Unfortunately some physicochemical parameters $(\mathrm{pH}$, temperature, sample temperature, Dornic acidity and relative humidity) when not controlled distort curds or if not make them inedible. Therefore, this study was conducted in five locations for two seasons in order to assess the effect of these parameters on the quality of curds. The general objective of this work is to know the direct role of these parameters on the curds in different localities. Specifically this study aims to identify the relationship between seasonal and regional variations of curds and lactic flora present in these products.

\section{Materials and Methods}

Work was carried out at the Laboratory of Veterinary Research and Zootechnical of Farcha in Chad to Health and Food Industry Services Foodstuffs of Animal Origin.

\subsection{Areas of sampling}

Five locations were selected for this study. This is N'Djamena, Sarh, Moundou, Abeche and Bongor (Figure 1). These areas were chosen based on animal concentration in the dry season but also depending on the development of businesses related to the dairy industry. 


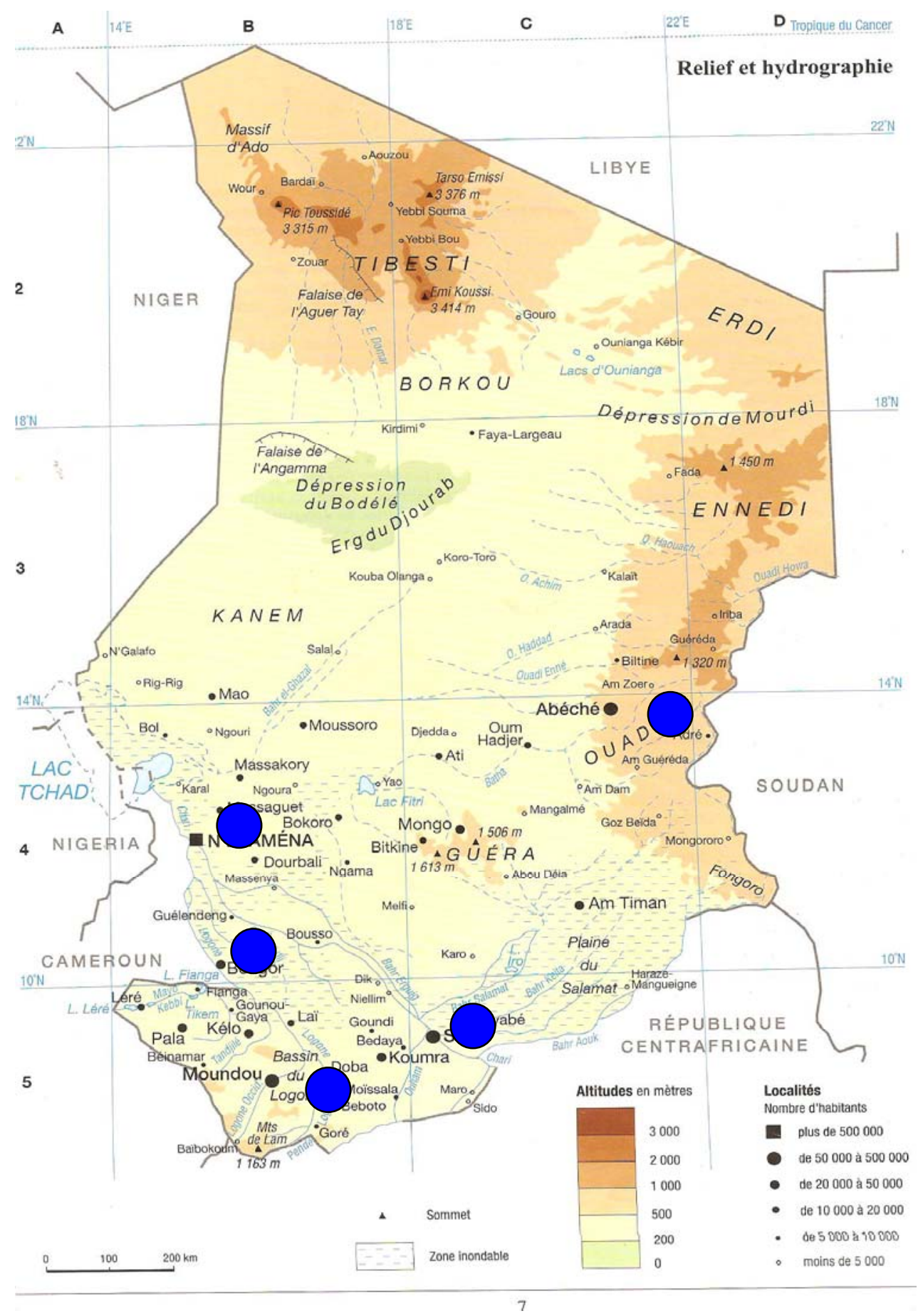

Figure 1. Location of study areas indicated by blue circles (Source: Jeune Afrique, 2006 amended)

\subsection{Sampling and equipment}

As Chad has several agro-ecological regions, it was necessary to have a representative in the quantity and quality of production areas curd samples. And for a period of two years, one thousand (1000) samples were taken at random, five hundred (500) during the cold dry 
season (October to December) and five hundred (500) during the hot dry season (March-May) in the same sites.

\subsection{Sampling method}

Samples of curds were collected as aseptic rules respecting rigorous hygiene standards. It consists of plastic pots of $250 \mathrm{ml}$ volume. By producer we take 10 samples of $250 \mathrm{ml}$ who all come from different cans of 40 liters. Identifications are made in indelible ink. This is to avoid sampling the curd having the same origin, or at least whose manufacturing practices are similar. Quickly, we introduce samples into the cooler to prevent microbial growth. Thus the chain is maintained to the storage location. This continues until one hundred samples suburban area. After sampling, the samples were quickly introduced into a cooler with bottles of dry ice and crushed ice to maintain samples at very low temperatures. We used as thermo-hygrometers and $\mathrm{pH}$ meter probe to allow us to measure the temperature, moisture and $\mathrm{pH}$ levels. All samples are kept in cold rooms at the Veterinary and Zoo Technical Research Laboratory of Farcha (LRVZ).

\subsection{Method of analysis in the laboratory}

Once the samples arrive, they are introduced into the cold rooms of the laboratory. But the next day we take to determine the Dornic acidity or titration. For this we take a volume of 10 $\mathrm{ml}$ curd is placed in a beaker, and then adds 2 to 3 drops of phenolphthalein $1 \%$. Then the beaker was shaken to homogenize the mixture. It added dropwise sodium hydroxide contained in the burette until the color changes from white to pink. The color should persist for at least 8 seconds. Reading the burette drop is made. We expressed the results Dornic degree $\left({ }^{\circ} \mathrm{D}\right)$ multiplying the result by 10 . The equipment used includes freezers and refrigerators, slide, balance precision weighing, test tubes, Petri dishes, bottles of $500 \mathrm{ml}$, pipettes of 1, 2, 3, 5 and $10 \mathrm{ml}$, hood laminar flow for sterilization ovens, water baths, autoclaves to sterilize culture media player colonies. Culture media are de Man Rogosa and Sharpe (MRS) and $\mathrm{M}_{17}$ broth, agar and glassware. They are rarely used except for research of lactic acid bacteria community. They were ordered from Spain (Barcelona). They are very selective with the exception of some spoilage bacteria that can grow there (Escherichia coli) environments. We have prepared four culture media, two plates and two broths. These are MRS and $\mathrm{M}_{17}$. The method of preparation is the same. After weighing the medium in the form of powder and determined the amount of distilled water, the mixture is introduced into a flask containing a little distilled water. Then the remainder of distilled water required is completed. We stir the bottle to mix the contents of the vial. Then the mixture is heated in a pot. When everything becomes homogeneous, the medium is sterilized in an autoclave. After that, it is cooled and placed in a water bath before use. By cons broth after cooling is kept in the refrigerator.

\subsection{Material of identification and confirmation}

For the different identifications of lactic acid bacteria, we used two types of galleries: Galerie API 20 STREP and API 50 CH gallery-L with their reagent kit. For confirmation we used catalogs identification. The software web api TM was used. 


\subsection{Research Methods of lactic acid bacteria}

All samples studied have undergone preliminary treatment to obtain dilutions according to standard NF V08 -010 (March 1996). We introduce in STOMACHER ${ }^{\mathrm{ND}}$ bag $10 \mathrm{ml}$ of the sample to which are added $90 \mathrm{ml}$ of MRS broth or broth or $\mathrm{M}_{17}$. Lactic flora was enumerated according to the NF ISO 15214 (September 1998). The culture media used are: broth and agar MRS for the enumeration of lactobacilli and $\mathrm{M}_{17}$ medium for the enumeration of streptococci. For each sample, the morphological characteristics of the colonies (size, shape, color) are observed. Lactobacillus colonies are round, lenticular, vary in size (1-4 mm), those of Streptococcus are round or lenticular, with regular contours, a white opaque.

\subsection{Identification and confirmation method (NF ISO 15214, September 1998)}

We must clarify that the wells after receiving tabs reagents are covered by a plastic cover to prevent contamination. For bacteria grown in MRS agar, we use the API $50 \mathrm{CH}$ galleries -L. On the cup with 50 stalls, we put a small amount of distilled water to be able to fix the plates that have compartments containing chemicals that are capable of reacting with the bacterial suspension with or without color change water. Indeed, it there's a note that explains the positivity or negativity of a reaction depending on the color and tell us the number to write. And so we get a code number and we will consult the grid for the name of the bacterium with a percentage of identification and testing against. For bacteria grown in $\mathbf{M}_{17}$ agar, the cup is more simplified and has only ten cubicles allowing the strip containing the reagents to adhere by putting a small amount of distilled water. Each stall is filled with the suspension is at half or three-quarters full. Some stalls are filled entirely from the paraffin oil for achieving anaerobiosis. For the $M_{17}$, there's a reading that it takes 2 hours and another $24 \mathrm{~h}$. MRS reading is at $24 \mathrm{~h}$ only. After reading the bacteria are identified. But to avoid any confusion the APIWEB TM software is used for the second time with the same code.

\subsection{Statistical Analysis}

The collected data are entered in the spreadsheet Microsoft Excel version 2003. Then to compare means, we used the SPSS 16. 0 software from WINDOWS including Student's t test and analysis of variance (ANOVA) with a factor.

\section{Results}

\subsection{Locality of Abeche}




\section{Macrothink}

Journal of Food Studies ISSN 2166-1073 2013, Vol. 2, No. 2

Table 1. Values of physicochemical parameters obtained in 2006 and 2008

\begin{tabular}{|c|c|c|c|c|c|c|c|l|}
\hline \multirow{2}{*}{ Palues } & \multicolumn{2}{|c|}{ Minimum } & \multicolumn{2}{c|}{ Maximum } & \multicolumn{2}{c|}{ Average } & \multicolumn{2}{c|}{ Comparison test } \\
\hline \multirow{2}{*}{$\mathrm{pH}$} & CDS & HDS & CDS & HDS & CDS & HDS & P & Signif \\
\cline { 2 - 10 } & 3 & 3.10 & 4.91 & 5.00 & 3.79 & 3.77 & 0.639 & $*$ \\
\hline $\begin{array}{c}\text { Sample Temp } \\
\left({ }^{\circ} \mathrm{C}\right)\end{array}$ & 26 & 27.32 & 32.33 & 40.87 & 28.15 & 35.19 & 0.000 & $* * *$ \\
\hline Ambient Temp ( $\left.{ }^{\circ} \mathrm{C}\right)$ & 27.34 & 36.05 & 34.53 & 44.99 & 30.96 & 40.06 & 0.000 & $* * *$ \\
\hline Dornic acidity $\left({ }^{\circ} \mathrm{D}\right)$ & 81 & 72 & 142 & 135 & 111.27 & 106.51 & 0.003 & $* *$ \\
\hline Humidity (\%) & 29 & 25 & 41 & 39 & 34.86 & 31.93 & 0.000 & $* * *$ \\
\hline
\end{tabular}

CDS $=$ Cold Dry Season; HDS $=$ Hot Dry Season; Signif $=$ signification; $*=$ Not significant; $* *=$ Signifiant; $* *=$ Very Signifiant

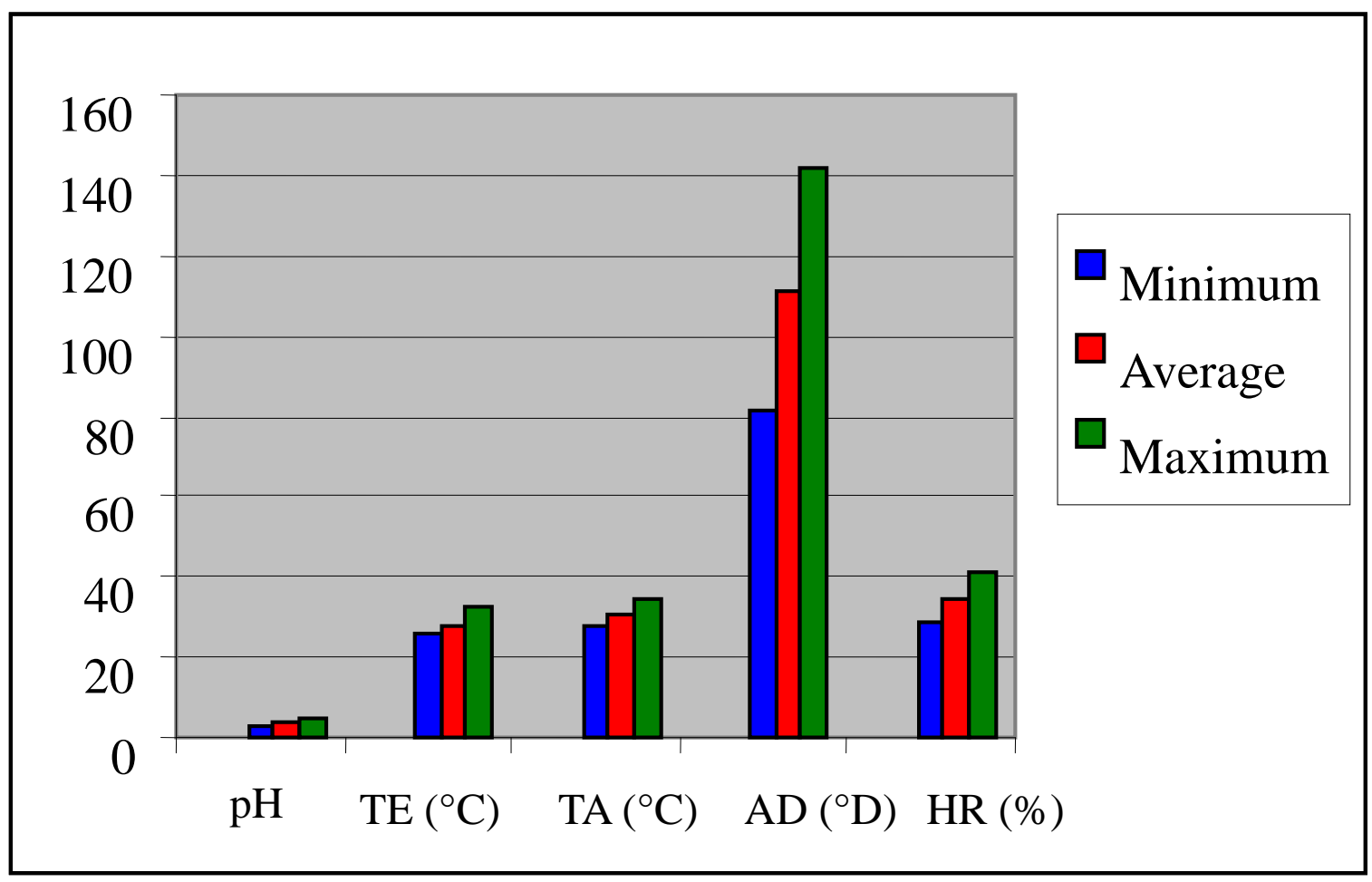

$\mathrm{TE}$ = Temperature of Sample; TA = Room Temperature; $\mathrm{AD}$ = Dornic acidity; HR = Relative Humidity

Figure 2. Physicochemical parameters of the town of Bongor on cold dry season 


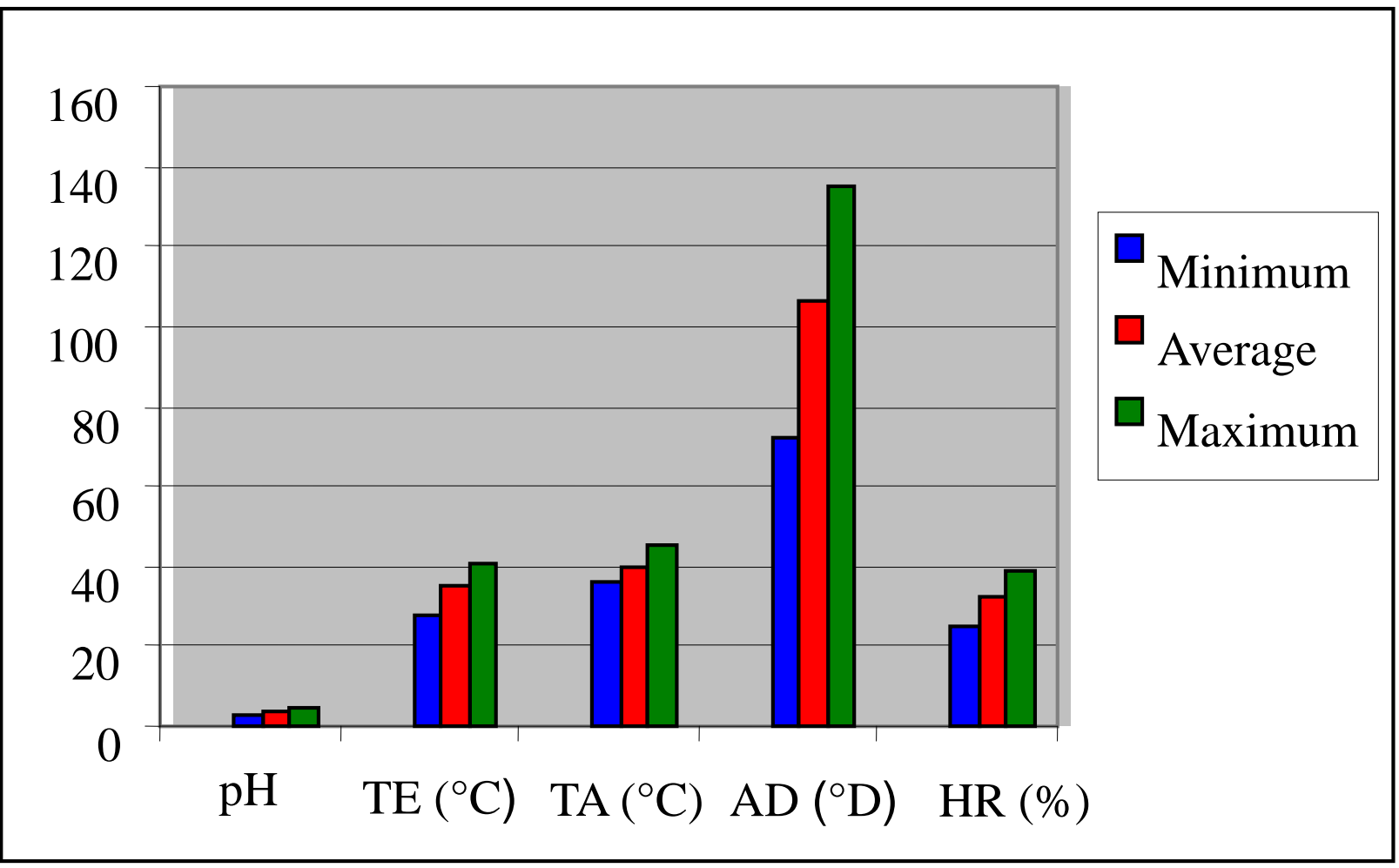

$\mathrm{TE}=$ Temperature of Sample; $\mathrm{TA}$ = Room Temperature; $\mathrm{AD}$ = Dornic acidity; HR = Relative Humidity

Figure 3. Physicochemical parameters of the town of Bongor on hot dry season

\subsection{Locality of N'Djamena}

Table 2. Values of physicochemical parameters obtained in 2006 and 2008

\begin{tabular}{|c|c|c|c|c|c|c|c|c|}
\hline \multirow{2}{*}{$\begin{array}{c}\text { Values } \\
\text { Parameters }\end{array}$} & \multicolumn{2}{|c|}{ Minimum } & \multicolumn{2}{c|}{ Maximum } & \multicolumn{2}{c|}{ Average } & \multicolumn{2}{c|}{ Comparison test } \\
\hline $\mathrm{pH}$ & CDS & HDS & CDS & HDS & CDS & HDS & P & Signif \\
\cline { 2 - 9 }$y$ & 3.13 & 3.00 & 4.56 & 5.00 & 3.92 & 3.75 & 0.000 & $* * *$ \\
\hline $\begin{array}{c}\text { Sample Temp } \\
\left({ }^{\circ} \mathrm{C}\right)\end{array}$ & 20.08 & 31.09 & 27.00 & 39.97 & 22.81 & 35.86 & 0.000 & $* * *$ \\
\hline $\begin{array}{c}\text { Ambient Temp } \\
\left({ }^{\circ} \mathrm{C}\right)\end{array}$ & 25.10 & 36.01 & 30.94 & 44.71 & 28.00 & 40.56 & 0.000 & $* * *$ \\
\hline $\begin{array}{c}\text { Dornic } \\
\text { Acidity }\left({ }^{\circ} \mathrm{D}\right)\end{array}$ & 57 & 74 & 128 & 135 & 99.75 & 106.45 & 0.000 & $* * *$ \\
\hline Humidity (\%) & 38 & 33 & 50 & 46 & 44.16 & 38.93 & 0.000 & $* * *$ \\
\hline
\end{tabular}

CDS = Cold Dry Season; HDS = Hot Dry Season; Signif = signification; * = Not significant; ** = Signifiant; $* *=$ Very signifiant 


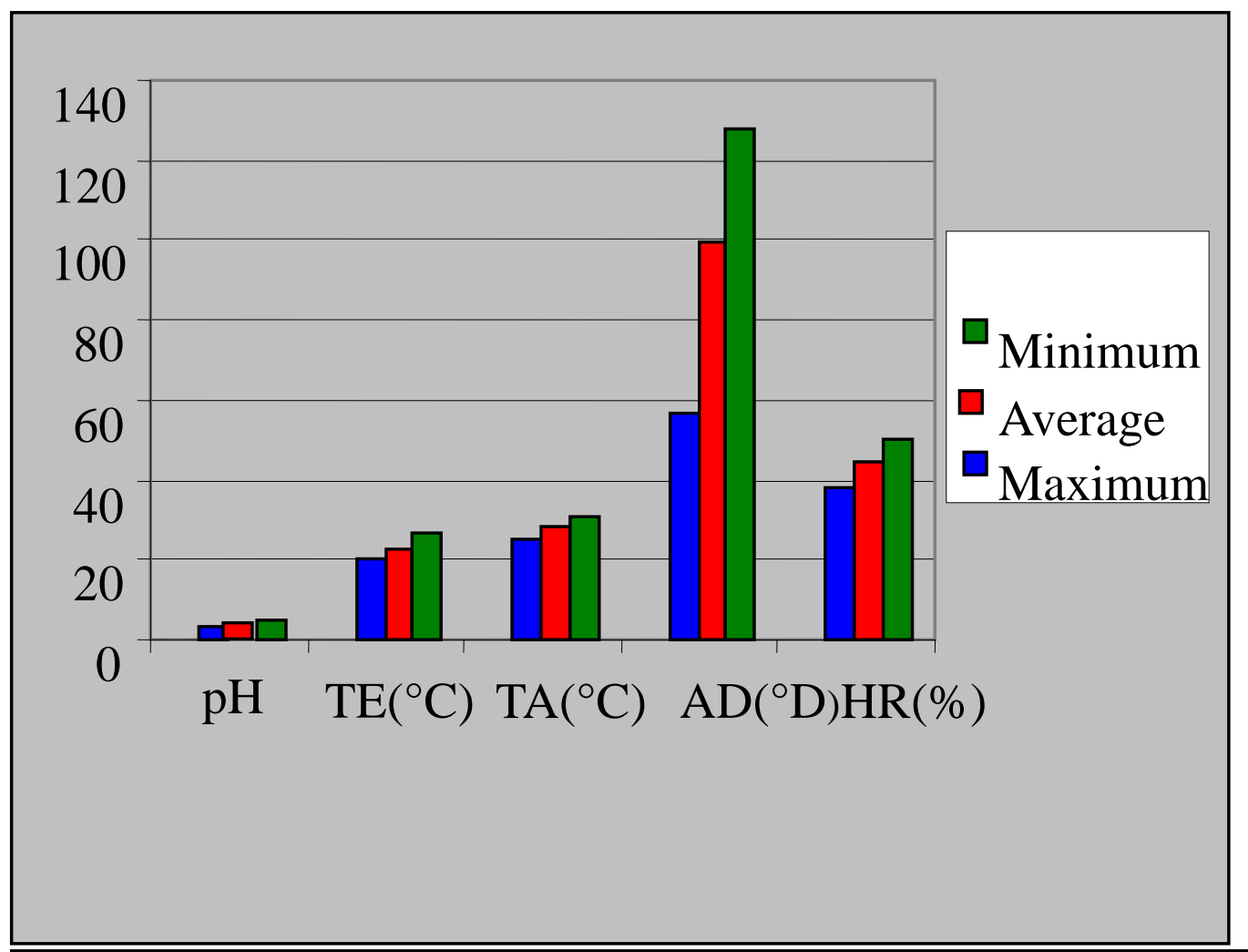

$\mathrm{TE}=$ Temperature of Sample; TA = Room Temperature; $\mathrm{AD}$ = Dornic acidity; HR = Relative Humidity

Figure 4. Physicochemical parameters of the town of N’Djamena on cold dry season

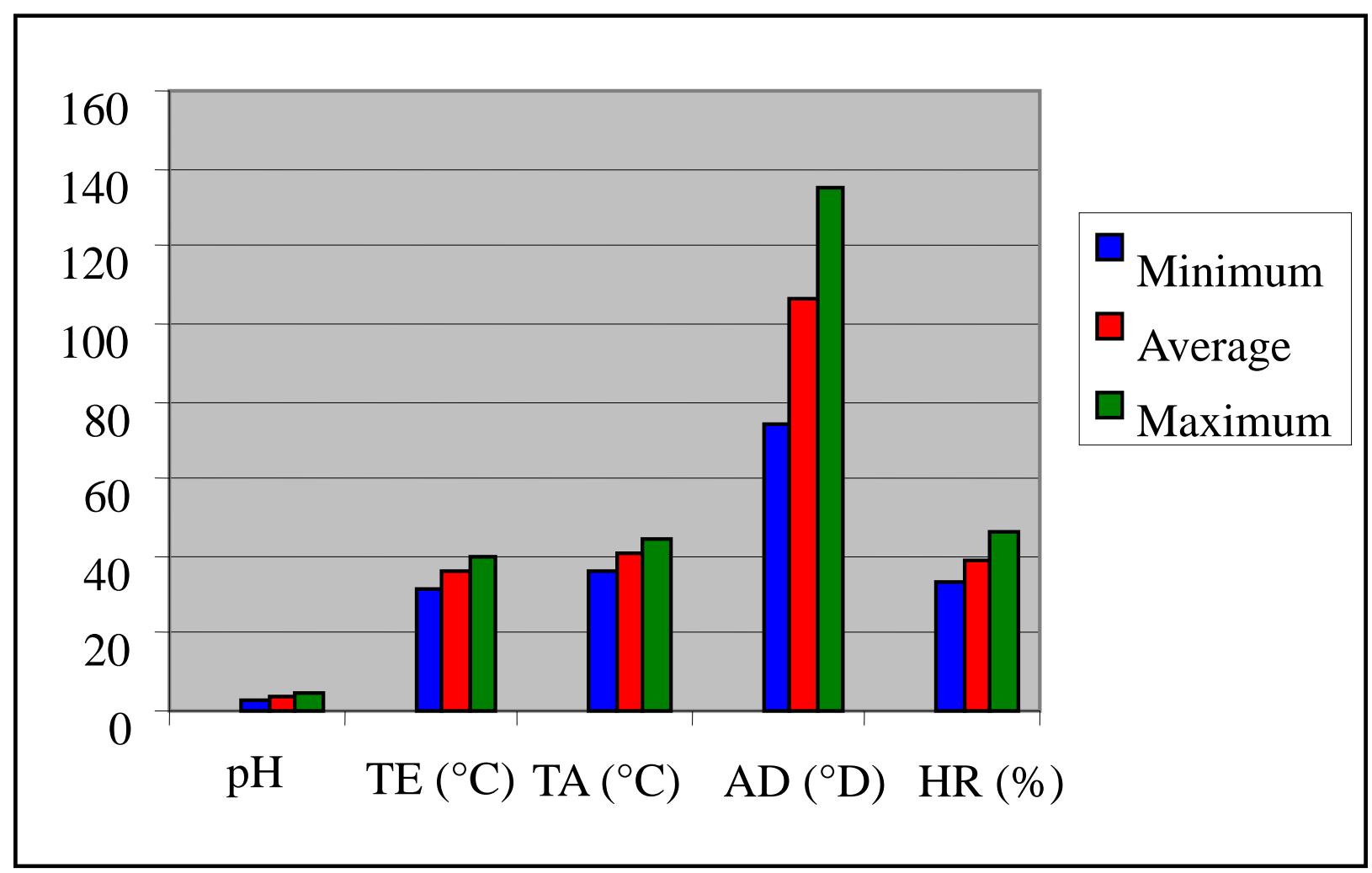


$\mathrm{TE}$ = Temperature of Sample; TA = Room Temperature; $\mathrm{AD}$ = Dornic acidity; HR = Relative Humidity

Figure 5. Physicochemical parameters of the town of N’Djamena on hot dry season

\subsection{Locality of Bongor}

Table 3: Values of physicochemical parameters obtained in 2006 and 2008

\begin{tabular}{|c|c|c|c|c|c|c|c|c|}
\hline Values & \multicolumn{2}{|c|}{ Minimum } & \multicolumn{2}{|c|}{ Maximum } & \multicolumn{2}{|l|}{ Average } & \multicolumn{2}{|c|}{ Comparison test } \\
\hline & CDS & HDS & CDS & HDS & CDS & HDS & $\mathrm{P}$ & signif \\
\hline $\mathrm{pH}$ & 3. 00 & 3. 38 & 5.00 & 4. 91 & 3. 82 & 4. 07 & 0.000 & $* * *$ \\
\hline Sample Temp $\left({ }^{\circ} \mathrm{C}\right)$ & 28.12 & 21.70 & 34.95 & 31.20 & 31.97 & 26.33 & 0.000 & $* * *$ \\
\hline Ambient Temp $\left({ }^{\circ} \mathrm{C}\right)$ & 28.40 & 26.00 & 38.42 & 35.50 & 33. 37 & 30.55 & 0.000 & $* * *$ \\
\hline Dornic Acidity $\left({ }^{\circ} \mathrm{D}\right)$ & 75 & 72 & 135 & 127 & 105. 27 & 96.34 & 0.000 & $* * *$ \\
\hline Humidity (\%) & 35 & 50 & 51 & 66 & 42. 95 & 59. 06 & 0.000 & $* * *$ \\
\hline
\end{tabular}

CDS = Cold Dry Season; HDS = Hot Dry Season; Signif = signification; $*=$ Not significant; $* *=$ Signifiant; ** = Very Signifiant

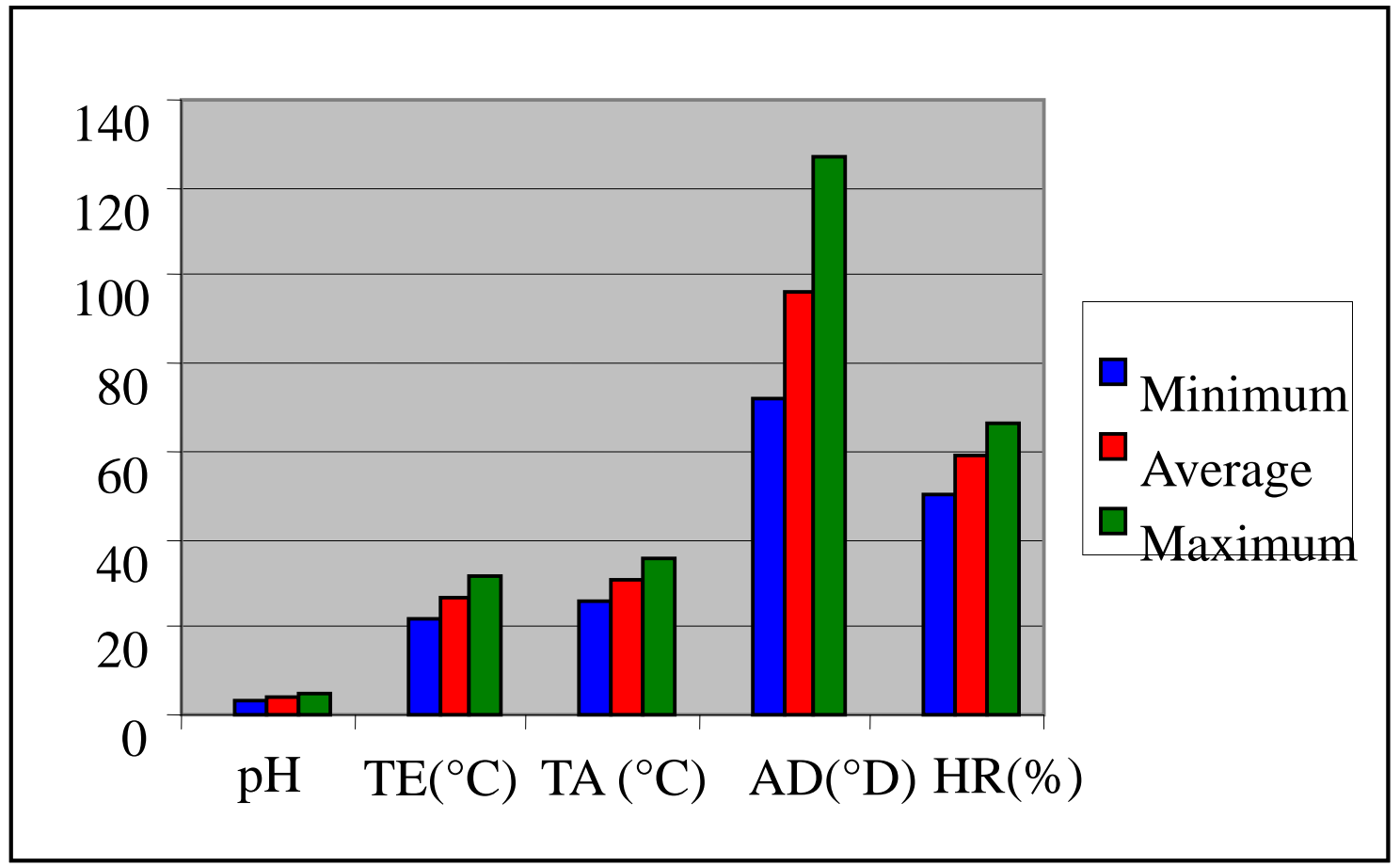

$\mathrm{TE}=$ Temperature of Sample; TA = Room Temperature; $\mathrm{AD}=$ Dornic acidity; HR = Relative Humidity

Figure 6. Physicochemical parameters of the town of Bongor on cold dry season 


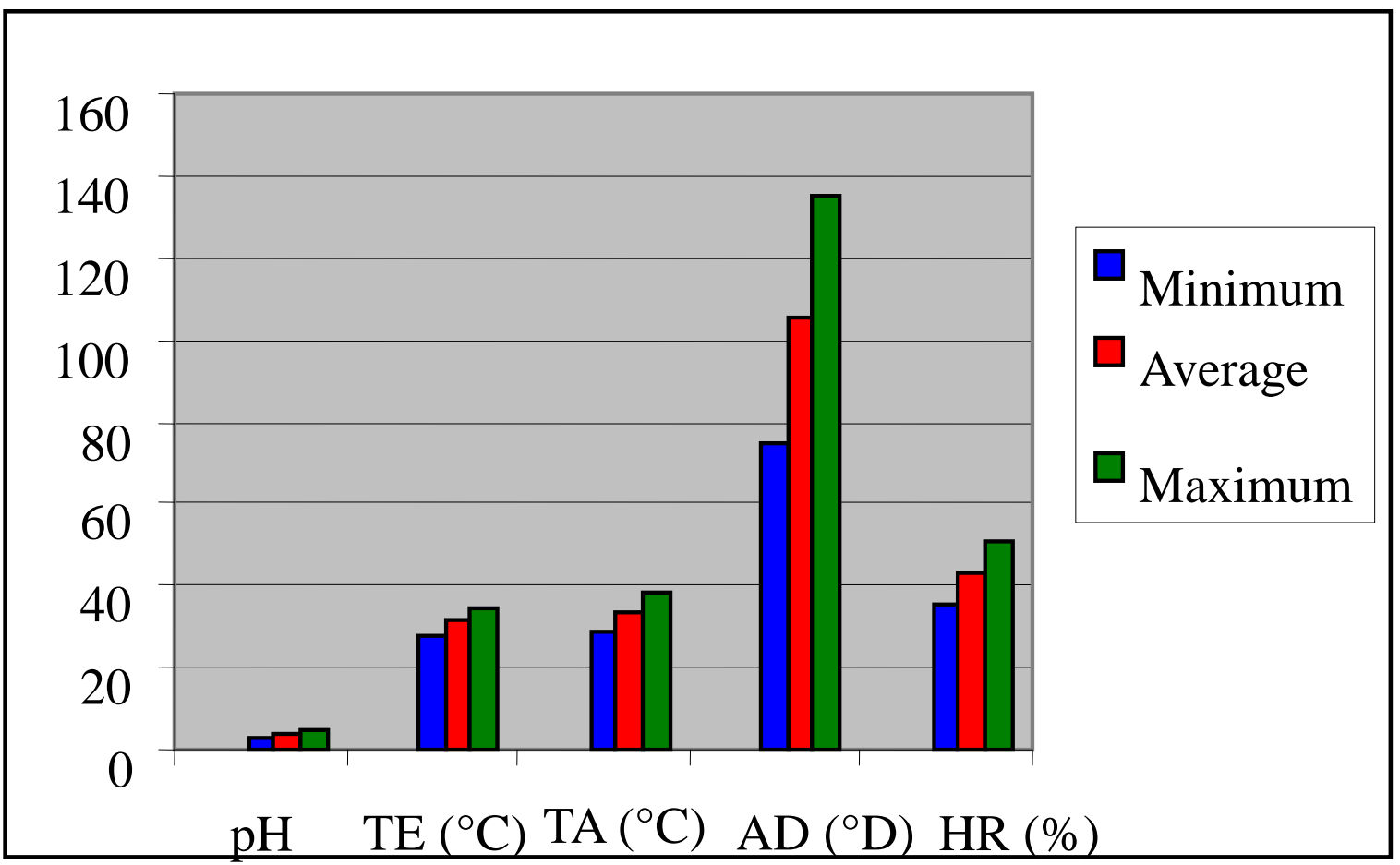

$\mathrm{TE}=$ Temperature of Sample; TA = Room Temperature; AD = Dornic acidity; HR = Relative Humidity

Figure 7. Physicochemical parameters of the town of N'Djamena on hot dry season

\subsection{Location of Sarh}

Table 4. Values of physicochemical parameters obtained in 2006 and 2008

\begin{tabular}{|c|c|c|c|c|c|c|c|c|}
\hline & \multicolumn{2}{|c|}{ Minimum } & \multicolumn{2}{|c|}{ Maximum } & \multicolumn{2}{|c|}{ Average } & \multicolumn{2}{|c|}{ Comparison test } \\
\hline & DCS & HDS & CDS & HDS & CDS & HDS & $\mathrm{P}$ & Signif \\
\hline $\mathrm{pH}$ & 3. 12 & 3. 00 & 4,75 & 5. 00 & 4. 06 & 3. 79 & 0.000 & $* * *$ \\
\hline Sample Temp $\left({ }^{\circ} \mathrm{C}\right)$ & 16. 04 & 26. 12 & 26. 71 & 33. 44 & 19. 01 & 29. 91 & 0.000 & $* * *$ \\
\hline Ambient Temp $\left({ }^{\circ} \mathrm{C}\right)$ & 19. 01 & 29. 23 & 30.02 & 36.52 & 24.77 & 33. 04 & 0.000 & $* * *$ \\
\hline Dornic Acidity $\left({ }^{\circ} \mathrm{D}\right)$ & 74 & 75 & 72 & 135 & 99.58 & 107. 12 & 0.000 & $* * *$ \\
\hline Humidity (\%) & 52 & 47 & 135 & 62 & 60.89 & 54.87 & 0.000 & $* * *$ \\
\hline
\end{tabular}

CDS = Cold Dry Season; HDS = Hot Dry Season; Signif = signification; $*=$ Not significant; $* *=$ Signifiant; $* *=$ Very 


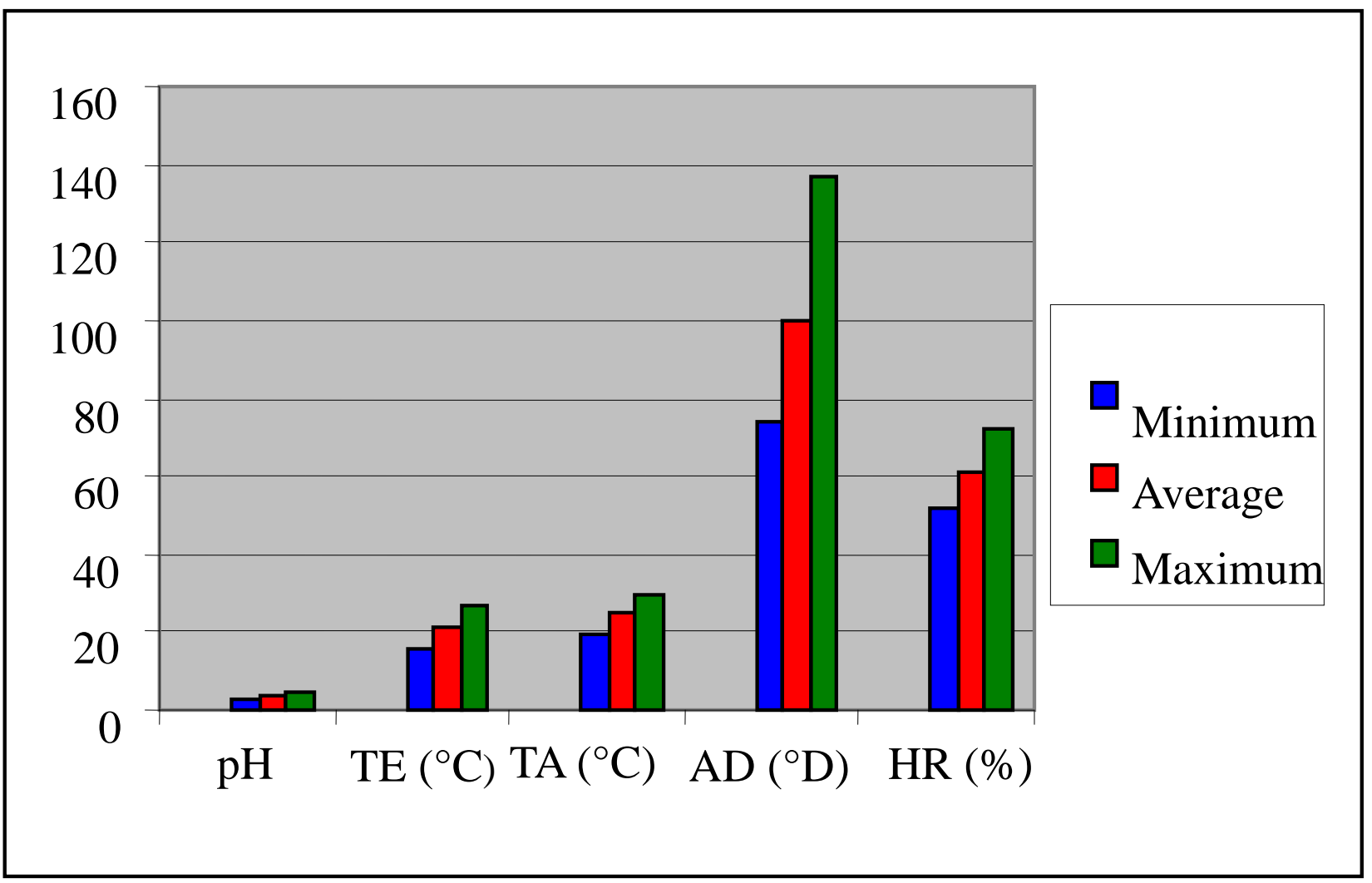

$\mathrm{TE}=$ Temperature of Sample; $\mathrm{TA}=$ Room Temperature; $\mathrm{AD}=$ Dornic acidity; HR = Relative Humidity

Figure 8. Physicochemical parameters of the town of Sarh on cold dry season

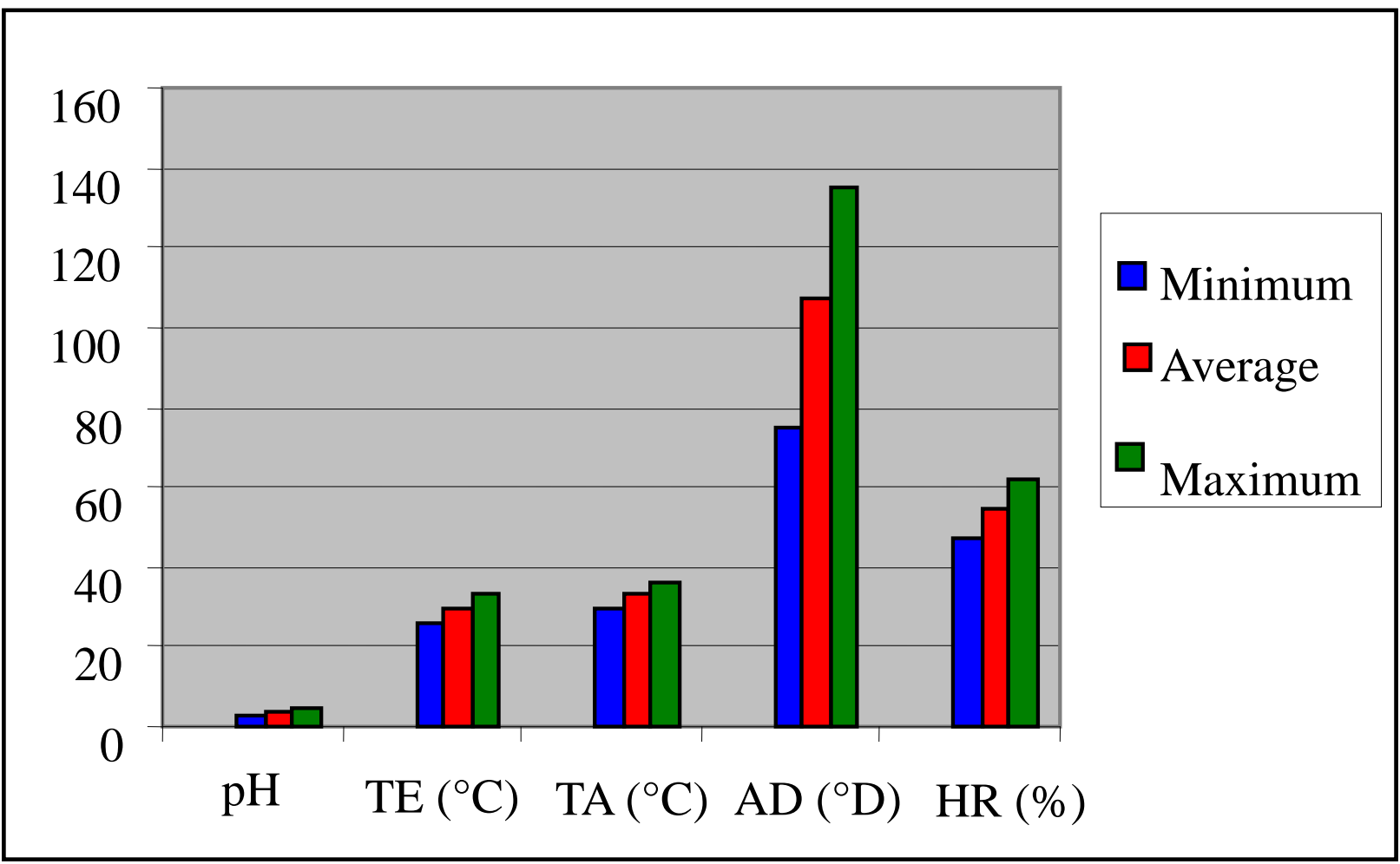


$\mathrm{TE}=$ Temperature of Sample; $\mathrm{TA}=$ Room Temperature; $\mathrm{AD}=$ Dornic acidity; HR = Relative Humidity

Figure 9. Physicochemical parameters of the town of Sarh on cold dry season

\subsection{Locality of Moundou}

Table 5. Values of physicochemical parameters obtained in 2006 and 2008

\begin{tabular}{|l|l|l|l|l|l|l|l|l|}
\hline $\begin{array}{l}\text { Values } \\
\text { Parameters }\end{array}$ & \multicolumn{4}{l|}{ Minimum } & \multicolumn{2}{l|}{ Maximum } & \multicolumn{2}{l|}{} \\
\hline \multirow{3}{*}{$\mathrm{pH}$} & CDS & HDS & SSF & CDS & HDS & CDS & P & Signif \\
\cline { 2 - 11 } & 3.37 & 3.00 & 5.00 & 5.00 & 4.19 & 3.83 & 0.000 & $* * *$ \\
\hline Sample Temp $\left({ }^{\circ} \mathrm{C}\right)$ & 21.35 & 26.12 & 30.00 & 36.43 & 25.33 & 31.18 & 0.000 & $* * *$ \\
\hline Ambient Temp $\left({ }^{\circ} \mathrm{C}\right)$ & 27.12 & 32.09 & 35.82 & 39.71 & 31.95 & 35.87 & 0.000 & $* * *$ \\
\hline Dornic acidity $\left({ }^{\circ} \mathrm{D}\right)$ & 70 & 75 & 127 & 135 & 93.02 & 104.65 & 0.000 & $* * *$ \\
\hline Humidity (\%) & 63 & 51 & 76 & 66 & 69.70 & 58.77 & 0.000 & $* * *$ \\
\hline
\end{tabular}

CDS = Cold Dry Season; HDS = Hot Dry Season; Signif = signification; * = Not significant; ** = Signifiant; $* *=$ Very Signifiant

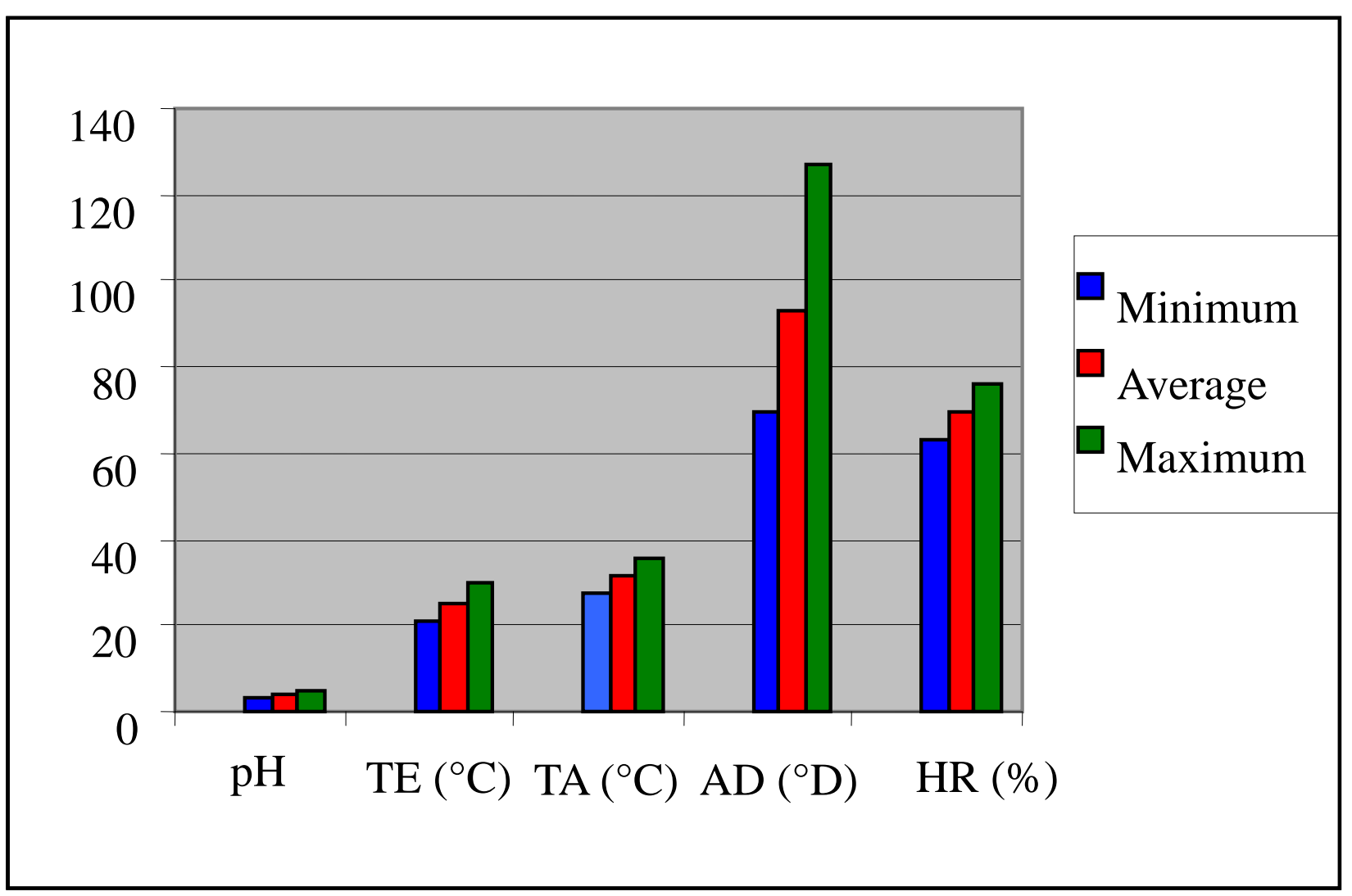

$\mathrm{TE}=$ Temperature of Sample; $\mathrm{TA}=$ Room Temperature; $\mathrm{AD}=$ Dornic acidity; $\mathrm{HR}=$ Relative Humidity 
Figure 10. Physicochemical parameters of the town of Moundou on cold dry season

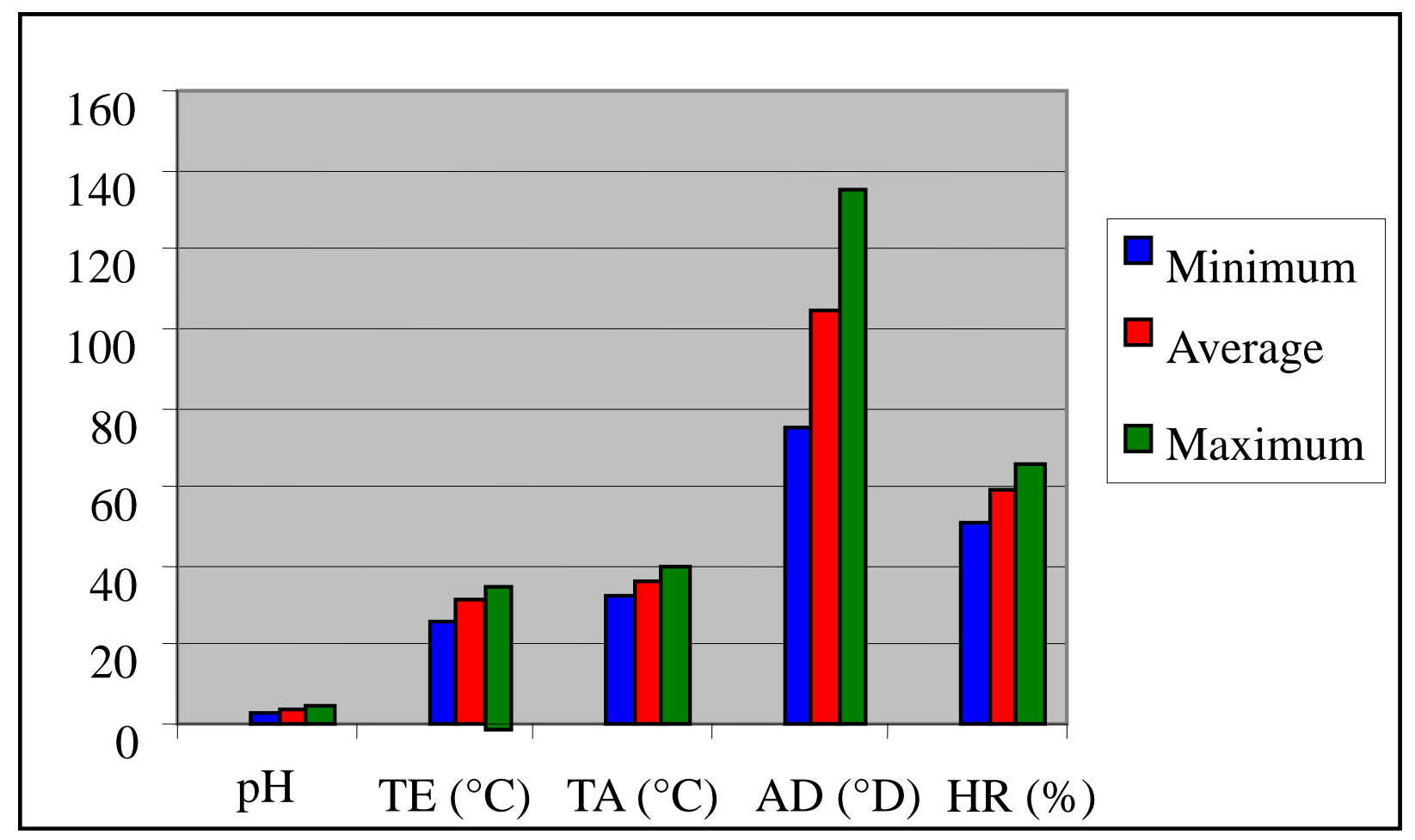

$\mathrm{TE}=$ Temperature of Sample; $\mathrm{TA}=$ Room Temperature; $\mathrm{AD}=$ Dornic acidity; HR = Relative Humidity

Figure 11. Physicochemical parameters of the town of Moundou on hot dry season

\section{Discussion}

We measured in our study, the following physico- chemical parameters of curds collected in Abeche, N'Djamena , Bongor Moundou and Sarh: pH, temperature of the sample, ambient temperature, relative humidity and acidity Dornic. Changes in the values of these parameters were also noted within the same locality in cold dry season and hot dry season between localities in the same seasons.

Compared to $\mathrm{pH}$ between the two seasons, it was noted slight differences in average in the town of Abeche of 3.79 against 3.77. The differences between the two seasons are not significant with $\mathrm{P}>0.05$. In the city of N'Djamena, the average $\mathrm{pH}$ was 3.92 against 3.75 during the hot dry season. These average values of $\mathrm{pH}$ between the two seasons for this locality have a very significant difference with $\mathrm{P}<0.01$. For the city of Bongor, average values are 3.82 and 4.07 for two seasons. There is a very significant difference between the two means with $\mathrm{P}<0.001$. At Sarh, where average values of 4.06 and 3.79, the difference between the two averages is highly significant with $\mathrm{P}<0.001$. The average $\mathrm{pH}$ is between seasons, 4.19 against 3.83 in Moundou. There is also a very significant difference between 
the two means with $\mathrm{P}<0.001$. In all locations, the average $\mathrm{pH}$ readings are higher in cold dry season ( 3.79 to $4.19^{\circ} \mathrm{C}$ ) than in hot dry season ( 3.75 to $3.83{ }^{\circ} \mathrm{C}$ ). This can be explained by the fact when it is very hot, the the $\mathrm{pH}$ decreases. Our results are lower than those obtained by Doutoum (1995) and are 4.11, but this author has worked on industrial milk curds. Our results are also lower than N'Diaye (1991), 4.17; Sina (1992) 4.75, Xantapoulos et al. (2006), 4.6 and Avila et al. (2005) 4. 33. These authors have also worked on industrial curd. Nko Sadi (2006) found a $\mathrm{pH}$ of curd at about 6.5. This $\mathrm{pH}$ is very high and can be explained by the fact that the measurements were made at the beginning of curdling. Chirica et al. (1998) reported that the optimum pH of lactic acid bacteria (Streptococcus thermophilus) is between 6 and 7. However it is rather $\mathrm{pH}$ of raw milk. But Fernandez et al. (2005) reported that another starter culture (Lactobacillus bulgaricus) grows at $\mathrm{pH} 2$ to 3.7. He argues that all lactic acid bacteria do not grow at a very acidic $\mathrm{pH}$. Bueno et al. (2006) obtained values varying $\mathrm{pH}$ but higher than ours (4.06, 4.02, 3.85) and that are optimal for the growth of lactic acid bacteria such as Lactobacillus casei and Lactobacillus rhamnosus. Sylla et al. (2005) found values close to ours with an average $\mathrm{pH}$ of 3.78. This compared to the yoghurt value is low ( $\mathrm{pH} 4)$. Reflecting the excessive acidity of fermented milk can be explained first by the fermentation technique used in this controller. This high acidity can also be explained by the freshness of the raw material. To this end, Abdelgadir (1998) and other authors have shown that milk may have the same $\mathrm{pH}$, so give the same stability in industrial processes and yet show significantly different acidities. Conversely, curds can have the same acidity and $\mathrm{pH}$ values; in this case, the observed differences are related to high solids content. Our results corroborate those of Dieng (2001), the study focused on industrial curdled milk: it found that $92 \%$ of the samples have a $\mathrm{pH}$ below 4.6. This $\mathrm{pH}$ inhibits the growth of pathogenic bacteria and ensures better preservation. Bouzaine et al. (2004) found different results from ours. Indeed they found a $\mathrm{pH}$ of 2 and it has a remarkable antimicrobial activity against pathogens and spoilage organisms. Yoon \& Woon (2002) found an average $\mathrm{pH}$ of 3.5. They showed that bacteria such as Lactobacillus acidophilus and Lactobacillus helveticus fight against pathogenic bacteria. Bae \& Lee (2002) obtained a pH higher (5.7) than ours and identified Lactobacillus bulgaricus including antibacterial activity. Ahn et al. (2002) reported very acidic $\mathrm{pH}$ (2.5) and identified Lactobacillus acidophilus which has activity against Salmonella spp, Salmonella enteritidis and Salmonella typhimurium. Kang et al. (2004) note that Lactobacillus fermentum multiplies at $\mathrm{pH} 2$ to 4. Finally Ziadi et al. (2005) obtained a $\mathrm{pH}$ of 4.30, which is a value much higher than ours, this is explained by the fact that they have worked on industrial curd including control of the cold chain.

Indeed we know that the mean values of the sample temperature varies during the hot dry season, they range from 29.91 to $35.19{ }^{\circ} \mathrm{C}$. With reference to the work of other authors, we can say that the $\mathrm{pH}$ values recorded during the hot dry season and cold dry season in all localities are conducive to the growth of lactic acid bacteria.

Regarding the sample temperature, the differences between the two means are very significant in all areas studied with $\mathrm{P}<0.001$. In all locations, we noted that the average temperature values of the samples are lower in cold dry season ( $22.81{ }^{\circ} \mathrm{C}$ to $28.19^{\circ} \mathrm{C}$ ) in hot dry season ( $29.91{ }^{\circ} \mathrm{C}$ to $35,19^{\circ} \mathrm{C}$ ). This can be explained by the fact that the temperature at 
the reception of the sample is strongly influenced by the ambient temperature, the mean values for our study ranged from $24.71{ }^{\circ} \mathrm{C}$ to $31.98^{\circ} \mathrm{C}$ in cold dry season and $33.31{ }^{\circ} \mathrm{C}$ to $41.06^{\circ} \mathrm{C}$ during the hot dry season. The average values of temperatures of samples we have identified are not unique, since similar values were noted by other authors. This is the case Sylla et al. (2005) noted that $30{ }^{\circ} \mathrm{C}$, Tahir (2007) recorded $29.14{ }^{\circ} \mathrm{C}$, Hassane \& Bremé (2007) noted $24{ }^{\circ} \mathrm{C}$ and Hadji \& Yalinga ( 2007) reported $23.12{ }^{\circ} \mathrm{C}$.

The average values of the ambient temperature have increased in all areas between the cold dry season $\left(24.71{ }^{\circ} \mathrm{C}\right.$ to $\left.31.98{ }^{\circ} \mathrm{C}\right)$ and the hot dry season $\left(33.31{ }^{\circ} \mathrm{C}\right.$ to $\left.41.06{ }^{\circ} \mathrm{C}\right)$. These are normal values for these seasons in Chad. The differences are very significant $\mathrm{P}<0.001$. The ambient temperature has a direct effect on the temperature of the sample. We must say that the temperature of the milk is strongly influenced by the ambient temperature. It can go up to $45^{\circ} \mathrm{C}$ (ASECNA-Chad, 2008). Ambient temperature is $41.06^{\circ} \mathrm{C}$ in dry hot season against 30.96 in dry cold season. The maximum is 44.99 and the minimum is 36.05 . This temperature rise can be explained by seasonal variation but also the location of the study area is semi-desert area. Ziadi et al. (2005) reported the same temperature but is control of the cold chain has to give the curd a satisfactory temperature.

Regarding the Dornic acidity, two lessons can be drawn from our analyzes . The first lesson is that in all localities except Abeche, the average values of the Dornic acidity are rated lower in cold dry season than in hot dry season. The second lesson is that in Abeche, the average values of the Dornic acidity is higher in cold dry season than in hot dry season and it is in this place that the highest value was observed $\left(111.27^{\circ} \mathrm{D}\right)$. Several explanations can be given to these observations. First of all the variations within the same locality development from Abeche, in the two seasons can be explained by the fact that in hot dry season , the increase in temperature causes a decrease in $\mathrm{pH}$ and therefore an increase in acidity Dornic . This is the opinion of Sylla et al. (2005) who observed an average of $77^{\circ} \mathrm{D}$ and for them the samples to high acidity Doronic have a low $\mathrm{pH}$. The elevation values of the Dornic acidity observed in Abeche in cold dry season and the hot dry season may be related to a high microbial activity. In other words, if acidity is higher, milk can be contaminated. Some authors have demonstrated this relationship. This is the case of N'Diaye (1991) who noted a medium acidity titration $152.6^{\circ} \mathrm{D}$ and showed that the curd was heavily contaminated with Escherichia coli, by yeasts and molds. This is also the case with Sina (1992) who reported values from 89 to $139^{\circ} \mathrm{D}$ with an absence of pathogenic flora but abundant flora alteration. For physico- chemical parameter variations were also observed between seasons within localities. So for the Abeche area the average value of the Dornic acidity increased during the two seasons from $111.27^{\circ} \pm 15.81^{\circ} \mathrm{D}$ to $106.5^{\circ} \mathrm{D} \pm 16.29$. For the locality of $\mathrm{N}^{\prime}$ Djamena, average of about $99.75^{\circ} \pm 13.85 \mathrm{D}$ increased to $106.45^{\circ} \mathrm{D} \pm 16,08$. In the town of Bongor the average value in the cold season is $96.34 \mathrm{D}^{\circ} \pm 15.15$.

The mean values of relative humidity in all localities are higher in cold dry season than in hot dry season. This is explained by the fact that the increase in temperature causes a decrease of humidity in the dry season. The recorded values are not exceptional because values similar to ours have been observed by other author: Tahir (2007) who's noted a value of 38\%, Hassane \& Bremé (2007) reported 46.27\%, Sobdibé (2007) noted 62\% and finally Hadj \&Yalinga 
reported a value of $72 \%$. The high relative humidity tends to keep longer curd.

\section{Conclusion}

This pioneering study has identified lactic species. In general, the physico-chemical characteristics of the analyzed products are pretty good. The products are not too acidic and organoleptic qualities, texture and color are acceptable. However, parameters such as temperature and acidity Dornic have been changes with the seasons. The average values of temperatures of samples increases as well as the average values of ambient temperatures during the hot dry season. In cold dry season, the average values of the Dornic acidity are higher. It was also identified species of bacteria that differ from one locality to another, but Streptococcus thermophilus, Lactococcus lactis diacetylactis, Lactococcus lactis cremoris, Lactococcus lactis lactis are present in all the five localities. Perspective further research in other areas and during the rainy season and will contribute greatly enhance this topic. They may also provide researchers with information that will be used in particular in the context of research and development.

\section{References}

Abdelgadir, W.S., Hamed, T.K. \& Dikar H.A. (1998). The traditional fermented milk products of the Sudan. International Journal of food-Microbio, 44, 1-13.

Ahn, Y.T., Lim, K.L., Ryu, J.C., Kang, D.K., Ham; J.S., Jang; Y.H., \& Kim H.V. (2002). Characterization of Lactobacillus acidophilus isolted from piglets and chiken. Asian-Aust. J. Anim. Sci, 15, 1790-1797.

Asecna-Tchad (2008). Rapport d'activités sur la situation climatologique au Tchad, N’Djaména, 79.

Avila, M., Garde, S., Medina, M., \& Nunez, M. (2005). Effect of milk inoculation with bacteriocin-Producing Lactic Acid Bacteria on a Lactobacillus helveticus Adjunct cheese culture. Journal of food protection, 68, 1026-1033.

Bouzaine, T., Elmajdoub, T., Thonart, Ph., \& Hamdi, M. (2004). Sélection des bactéries lactiques probiotiques d'origine animale Microb. Hyg. Alim., 16, 31-36.

Bueno D.J., Silva J.L., Olivier G., \& Gonzales S.N. (2006). Lactobacillus casei CRL 431 and Lactobacillus rhamnosus CRL1224 as Biological Controls for Aspergillus flavus Strains. Journal of Food Protection, 69, 2544-2548.

Chirica L.C., Guray T., Gurukan G.C., \& Bozoglu T.F (1998). Characterisation of extracellular Lactamases from Penicillin G-Resistant cells of Streptococcus thermophilus. Journal of Food Protection, 61, 896-897.

Chye, F.Y., Abdullah, A., \& Ayob, M.K. (2004). Bacteriological quality and safety of raw milk in Malaysia. Food Microbiol, 21, 535-541. http,//dx.doi.org/10.1016/j.fm.2003.11.007

Coulon, J.B., Pradel, P., \& Verdier, I. (1995). Effect of forage type on milk yield, chemical composition and clotting properties of milk. Lait, 75, 513-521. 
http,//dx.doi.org/10.1051/lait,1995640

Dieng, M. (2001). Contribution d'étude de la qualité microbiologique des laits caillés industriels commercialisés sur le marché Dakarois. Th. Méd. Vét, Dakar, 10.

Doutoum, A.A, Tidjani, A., Sylla, K.S.B., Tidjani, S. M. T., Alambedji, R.B., Balde, M., Abdelaziz Arada, I., Seydi, M.G., \& Toguebaye, B.S. (2013b). Identification of lactic acid bacteria in traditional curd inthe Sudanian zone of Chad. International Research Journal of Microbiology (IRJM) (ISSN, 2141-5463), 4(5), 119-124,

Doutoum, A.A. (1995). Contribution à l'étude de la qualité du lait des ceintures laitières périurbaines de la zone cotonnière du Sénégal.Th. Méd. Vét., EISMV, Dakar, $N^{\circ}, 21,144 \mathrm{p}$.

Doutoum, A.A., Tidjani, A., Abdelaziz Arada, I., Tidjani, S.M.T., Balde, M., Sylla, K.S.B., Seydi Mg., \& Toguebaye, B.S. (2013a). Identification of the lactic microorganism responsible for milk coagulation in Abeche (Chad). Afr. J. Food Sci. 7(5), 103-106.

Drewnowski, A. (2005). Concept of a nutritious food, Towards a nutrient density score. Am. J. Clin. Nutr., 82, 721-732.

Duteurtre, G., Koussou, M.O., \& Souleyman, A. (2005). Les bars laitiers à N’Djamena. Des petites entreprises qui valorisent les laits de brousse. In, Raymond C., Garine E., Langlois O. (eds). Ressources vivrières et choix alimentaire dans le bassin du Lac Tchad. IRD, CNRS, Coll. Colloques et séminaires, pp 435-456.

Fernandez, M.F., Delgado, T., Boris, S., Rodriguez, A., \& Barbes, C. (2005). A washed-curd Goat's cheese as a vehicle for Delivery of a Potential Probiotic Bacterium, Lactobacillus delbrueckii subsp lactis. Journal of Food Protection, 68, 2665-2671.

Hadji, A. O., \& Yalinga, D. (2007). Etude de la qualité microbiologique du lait consommé dans la zone de Moundou, recherche des ferments lactiques et de la flore globale. Mem. Ing. Elev. N’Djaména, 21, 38 p.

Hassan, A., \& Bremé, O M. (2007). Recherche des bacteries lactiques dans le lait caillé de la zone periurbaine de N’Djaména. Mém. Ing. Elev,N’Djaména, 12 , 47p.

Kang, D.K., Oh, H.K., Ham, J.S., Kim, J.G., Yoon, C.H., Ahn, Y.T., \& Kim, H.U. (2005). Identification and characterization of hydrogen peroxyde-generating Lactobacillus fermentum CS 12-1. Asian-Aust. J. Anim. Sci., 18, 90-95.

Koussou, M.O. (2001). L’approvisionnement de la ville de N’Djamena en produits laitiers. In, Duteurtre $G$ et Meyers C. (eds), marchés urbains et developpement laitier en Afrique subsaharienne. Acte de l'atelier international, 9-10 septembre 1998, Montpellier France, pp 75-80.

Miller, G. D., Jarvis, J. K., \& McBean, L. D. (2007). Contribution of dairy foods to health throughout the life cycle. In Handbook of dairy foods and nutrition (3rd ed.), 339-399. Boca Raton, FL, USA, CRC Press.

Ndiaye, M. (1991). Contribution à l'étude comparée de la qualité microbiologique des laits 
crus - laits caillés et laits en poudre commercialisés dans la région de Dakar - Sénégal. Th. Méd. Vét.EISMV, Dakar, 17. 112 p.

Nko Sadi, B. (2006). Appréciation de la mise en œuvre de l'hygiène dans une laiterie artisanale de Dakar LE DIRFEL, de la récolte du lait à sa transformation en lait caillé dit SOW PUR.Th. Méd. Vét. EISMV, Dakar, 26. 113 p.

Sina, L. (1992). Contrôle de qualité du lait et des produits laitiers fabriqués par la SOCA. Th. Méd. Vét. EISMV, Dakar, 33, 223.

Sobdibé, N. (2007). Recherche des bactéries lactiques des genres Lactobacillus et Streptococcus dans les produits laitiers à Bongor. Mem. Ing . Elev, N’Djaména, 10, 59.

Soryal, K.A., Zeng, S.S., Min, B.R., \& Hart, S.P. (2004). Effect of feeding treatments and lactation stages on composition and organoleptic quality of goat milk domiati cheese. Small Ruminant Res., 52, 109-116. http,//dx.doi.org/10.1016/S0921-4488(03)00249-9

Sutton, J.D. (1989). Altering milk composition by feeding. J. Dairy Sci., 72, 2801-2814. http,//dx.doi.org/10.3168/jds.S0022-0302(89)79426-1

Sylla, K.S.B., Musabyemariya, B., \& Seydi, Mg. (2005). Appréciation de la stabilité des laits (frais et caillés) produits par une unité de transformation laitière artisanale au Sénégal. RASPA, 3(2), 99-103.

Tahir, M. (2007). Recherche des bactéries lactiques dans les laits caillés de la zone periurbaine d’Abéché Mem. Ing. Elev., N’Djaména, 3 ,45p.

Takahiro, M., Nobuhiko, K., \& Toshinao, G. (2007). Milk consumption does not affect body mass index but may have an unfavorable effect on serum total cholesterol in Japanese adults. Nutr. Res., 27, 395-399. http,//dx.doi.org/10.1016/j.nutres.2007.05.006

Xanthopoulos, D., Petridis, N., \& Tzanetaki. (2006). Characterization and classification of Streptococcus thermophilus and Lactobacillus delbruecki subsp bulgaricus strains isolated from traditional Greek yogurts. Journal of food science, 66, 747-752. http,//dx.doi.org/10.1111/j.1365-2621.2001.tb04632.x

Yoon, Y.H., \& Woon, B.R. (2002). Antagonism against Helicobacter pylori and proteolysis of Lactobacillus helveticus CU 631 and Strain identification Asian-Aust. J. Anim. Sci., 15, 1050-1065.

Ziadi, M., Ayed, L., Mahmoudi, N. Ghorbel, Achour M., Thonart, P., \& Hamdi; M. (2005). Effet des ferments lactiques sur l'acidification et la rhéologie du Leben. Microbiol. Hyg. Ali., 17(50), $19-24$. 